\title{
THE MOTILE (CRYSTALLOLITHUS HYALINUS \\ GAARDER \& MARKALI) AND NON-MOTILE PHASES IN THE LIFE HISTORY OF COCCOLITHUS PELAGICUS (WALLICH) SCHILLER
}

\author{
By Mary Parke and Irene Adams \\ The Plymouth Laboratory \\ (With 43 Figures on Plates I-IV)
}

A new coccolithophorid, Crystallolithus hyalinus, was described with the help of electron micrographs by Gaarder \& Markali in 1956 from preserved material in which the cells lacked the appendages. From temporary cultures set up from our September 1957 sea-water samples a coccolithophorid was isolated which appeared, under the light microscope, very similar to this newly described coccolithophorid but which possessed, as does the genus Chrysochromulina, a coiling haptonema in addition to the two flagella. Electron micrographs, taken for us by Prof. I. Manton, have shown that the holococcoliths from our organism are identical in structure with those from the Crystallolithus hyalinus (cf. Pl. I, and Gaarder \& Markali, 1956, pl. I).

In addition, we have shown by culturing that the motile $C$. hyalinus bearing holococcoliths (crystalloliths) is in fact the motile phase in the life history of another coccolithophorid previously known only in the non-motile phase. This non-motile phase, bearing heterococcoliths (placoliths) which are structurally different from those borne on the motile phase, can be referred to the well-known species Coccolithus pelagicus (Wallich) Schiller.

The finding of two distinct structural types of coccoliths (see Braarud, Deflandre, Halldal \& Kamptner, 1955; Halldal \& Markali, 1955; Kamptner, I958) in the life history of one coccolithophorid will necessitate a complete reassessment of the problems connected with the classification of the Coccolithophoridae.

Very grateful thanks are due to Prof. Irene Manton for examining our organism under the electron microscope and for compiling for us Plate I of this paper. We are also indebted to Dr L. H. N. Cooper and Mr E. I. Butler for the collection of sea-water samples, and to Mrs B. Hepper for testing this organism for its possible toxicity to fish. 


\section{THE MOTILE 'CRYSTALLOLITHUS' PHASE}

As two strains (Plymouth no. I82, at position $50^{\circ} \mathrm{O2}^{\prime} \mathrm{N}$., $04^{\circ} 22^{\prime}$ W., at $10 \mathrm{~m}$ on 17 September 1957, deposited with the Collection of Algae and Protozoa, Cambridge; Plymouth no. 217, at position $47^{\circ} 19^{\prime} \mathrm{N} ., 07^{\circ} 23^{\prime} \mathrm{W}$., at $20 \mathrm{~m}$ on 20 April 1958) are being maintained in the Plymouth culture collection, additional information from living material can be given to supplement the description given by Gaardner \& Markali from preserved material.

The Crystallolithus phase swims only for short periods in one direction and moves comparatively slowly, rotating slowly also but showing sometimes considerable gyration. It can swim with the flagella and haptonema in front, or behind the body with the haptonema coiled or extended. As in some Chrysochromulina species (Parke, Manton \& Clarke, I955, I956) swimming is more rapid when the flagella and haptonema are directed backwards, but unlike most of the Chrysochromulina species in which the haptonema is coiled during rapid swimming, the haptonema in this form is seen more usually fully extended when swimming in either direction.

In culture the cells of this phase are globose to subglobose, measuring 8-I8 (exceptionally 6-20) $\mu$ in diameter (in a rapidly growing culture $18 \%$ of the cells are 6-IO $\mu, 55 \%$ IO-I $5 \mu$, and $27 \%$ I 5-20 $\mu$ ). The uninucleate cells have two or four deep golden brown parietal saucer-shaped to oblong chromatophores, deeply cleft into two at the non-flagellar pole. Conspicuous lipid bodies lie near the inner faces of the chromatophores, and leucosin vesicles are developed towards the non-flagellar pole. Two acronematic flagella, usually homodynamic, and one haptonema arise close together at one pole (Pls. I, II). The flagella are very fine and rather stiff, equal or unequal in length, $\mathrm{I} \cdot 5-2 \cdot 5$ times the cell diameter in length. There can be a difference of up to $6 \mu$ in the length of the two flagella of an individual cell. The short haptonema, thinner than the flagella and coiled round once or twice when not extended as a rod, usually measures $\frac{1}{2}$ to $\frac{3}{4}$ of the cell diameter in length when fully extended; it has a small club-shaped tip and shows a basal swelling (Fig. 2, Pl. I) similar to that found in Chrysochromulina kappa (Parke et al., 1955, pl. IV) and C. ericina (1956, pl. II).

The periplast of the cell has embedded, in its surface layer, very thin transparent oval to elliptical sculptured plate-scales, the sculpturing being visible only with the electron microscope. The scales show on one face a radiating pattern of ridges which reach to the edge (Fig. 4, Pl. I), while the other face usually shows either a network of fibres (Fig. 5, Pl. I) or sometimes roughly concentric surface ridges of varying width. In any one cell the scale size can range from 0.4 to $3.3 \mu$ in diameter but the most frequent size is from I. 5 to $2 \cdot 0 \mu$.

The Crystallolithus phase of Coccolithus pelagicus differs from the motile phases of members of the genus Chrysochromulina in having calcite micro- 
crystals deposited on the scales, and also apparently in the composition of the periplast. In addition to showing that scale size is extremely variable the electron micrographs have shown also that the calcite microcrystals, deposited on the scales in a definite pattern, the 'holococcolith' or 'crystallolith' (Braarud et al., 1955), vary considerably in size depending on scale size. Scales below I $\mu$ show no crystals, but scales about $\mathrm{I} \mu$ in length show a deposit of microcrystals which are clearly distinguishable (see centre Fig. 3, Pl. I). The edge length of the microcrystals can vary from 430 to $2500 \AA$ according to the size of the scale.

In the Crystallolithus phase the body has a two-layered covering, an inner distinct layer, which is clearly visible in Figs. 13-16, P1. II, and an outer hyaline striated layer in which the scales, bearing the crystalloliths on their outer face, are embedded (Figs. 8-I6, P1. II). With Schultze's solution the inner layer gave a reaction suggesting cellulose, but the outer hyaline layer failed to give any reaction for pectic material with Ruthenian Red; its composition therefore is unknown. This outer hyaline layer varies very considerably in thickness in different individuals, the range of thickness being from apparently absent (Fig. 7, P1. II) to being about $2.5 \mu$ thick (Figs. 8-I6, Pl. II). The change in thickness of this outer layer will be dealt with in the section on reproduction.

Frequently more than one layer of crystalloliths can be distinguished in this outer striated layer (Figs. II, I3, I6, P1. II) but in spite of these layers of material surrounding the body, the Crystallolithus phase can exhibit phagotrophy as do the marine species of Chrysochromulina that have been studied (Parke et al., 1955, 1956, 1958, 1959). Phagotrophy occurs very frequently, the cells ingesting graphite, bacteria and plant cells up to a size of $5 \mu$ (Figs. 27, 28, P1. III). Ingested material is taken in at the non-flagellar pole and is digested usually in the region towards that pole. An unusual procedure for the discarding of waste material then occurs which has not previously been recorded, although the discarding of empty walls of plant cells through a tube was reported for Chrysochromulina ericina (Parke et al., 1956, p. 398). In the Crystallolithus phase waste material, still in active Brownian movement, is passed out of the body into the outer hyaline layer where it collects in a globule (or vacuole) which is pushed out gradually from the hyaline layer, taking part of this layer with it including the crystalloliths. It is then cut off from the cell surface and discarded as a sack or sphere. This process takes place more usually near the non-flagellar pole, but it has been seen to occur near the flagellar pole. The discarded globules can measure up to $7.5 \mu$ in diameter. Under dark field it can be seen clearly that they are covered by coccoliths, and filled with minute granules still in active Brownian movement, but in preserved material these discarded globules could quite easily be mistaken for small coccolithophorids. The Crystallolithus stage has been tested and found non-toxic to fish. 
Reproduction of the motile Crystallolithus phase is by fission to produce generally two daughter-cells of equal or unequal size. Incipient fission stages (Fig. I5, P1. II) measure I 8-2I $\mu$ in diameter but double fission stages producing more usually three daughter-cells but occasionally four and measuring 28-30 $\mu$ in diameter are not uncommon (cf. Chrysochromulina, Parke et al., I955, figs. II, 44, 70). In the incipient fission stages the outer hyaline layer containing the crystalloliths has reached its maximum thickness and during fission appears to swell up and become detached from the body surface so that the two daughter-cells when they have rounded off lie free inside it. The daughter-cells emerge from this outer layer leaving it behind as an empty case (Fig. 3I, P1. IV) and in cultures the bottom of the flasks have a thick covering of these empty cases which persist for a considerable time. In the newly liberated daughter-cells (Fig. 7, P1. II) the hyaline layer cannot be detected although both it and the sculptured scales may be present. The crystalloliths are definitely not developed at this stage but as the daughter-cell secretes a new hyaline covering, apparently in concentric layers, the crystalloliths are gradually produced on the scales (Figs. 8-I4, Pl. II). Although the usual procedure is for the daughter-cells to emerge from the outer clear layer as 'naked' stages it is not unusual for the outer hyaline layer of the mother-cell, or part of it, to remain attached to the outside of the daughter cells so that when the new hyaline layer of the daughter-cell containing the crystalloliths is laid down, there is a second outer layer containing crystalloliths covering part of, or the whole of, the cell (Fig. I3, P1. II).

\section{THE NON-MOTILE COCCOLITHUS PELAGICUS PHASE}

The stages in the life history found so far suggest very strongly a type of life history similar to that found in the Chrysochromulina species that have been studied (cf. Parke et al., I955, p. 593). The motile Crystallolithus cells pass into the non-motile phase when a culture is $5-8$ weeks old. The cells collect on the bottom of the flask as a dark olive brown skin, which, if examined soon after its formation, shows masses of Crystallolithus-sized cells, the majority of which still retain the outer hyaline layer containing the crystalloliths (Fig. I6, P1. II; Figs. I9, 29, P1. III). At this early stage the cells, although lacking flagella, appear to retain their haptonemata as organs of attachment, as do the cells of the coccolithophorid, Pleurochrysis scherffelii Pringsheim, during the early stages of the non-motile phase. If samples of this skin from a Crystallolithus culture are not examined until about 2 weeks after its formation then the non-motile stages illustrated on Pl. III can usually be found. Among the smaller non-motile Crystallolithus individuals (Fig. I9), cells of much larger size $(25-60 \mu)$ have developed (Figs. 20-26) but their origin has not so far been traced. Fusion stages have been looked for consistently in cultures in this stage, but without success. Although knowledge 
of the first stage in the production of the large cells is lacking (cf. Chrysochromulina, Parke et al., 1955, p. 593), unless it is just a type of cyst formation in which there is a gradual increase in cell size, the later stages in their development have been recorded. Whether or not the initial stage in the production of the large cells is a fusion of two cells there is still further enlargement during the later stages of development.

In the earlier stages of enlargement the cells $(25-35 \mu)$, still surrounded by the hyaline layer (Fig. 20), develop very large leucosin vesicles, which can fill up to three quarters of the volume of the cell (Figs. 20, 2I). Later stages show either four (Fig. 30) or eight disk-shaped chromatophores (Fig. 22) and leucosin vesicles usually of smaller size. With further increase in cell size $(35-60 \mu)$ the leucosin reserve disappears (Fig. 20, bottom cell), the chromatophores become more lobed (Fig. 23) and numerous spheroidal to ovoid vesicles $(2.5-5.5 \mu)$, which darken on the outside with osmium tetroxide, gradually develop in the cells (Figs. 24-26). The production of these vesicles is an indication that the large placoliths of the Coccolithus pelagicus phase are beginning to form inside the cell. Single placoliths have been seen inside these large cells which still retain a very thin outer hyaline layer round the body (Fig. 26).

Normally the placoliths are deposited on the cell surface inside the thin hyaline layer (Fig. I7, P1. II) before the double division of the large $C$. pelagicus mother-cell (Figs. 32, 36) to produce four $C$. pelagicus daughtercells (Figs. 38-40, 42, 43); nevertheless, fission of the mother-cell into two (Fig. 25, P1. III) or four (Fig. 26, P1. III) can start while the placoliths are being deposited on the body surface. Our measurements of the different stages indicate that the mother-cells contract considerably in size while the placoliths are being deposited on the body surface (cf. similar stage in Chrysochromulina species, 1955, p. 593).

In culture, both the Coccolithus pelagicus mother- and daughter-cells show a wide range in size. The mother-cells are usually ovoid (Figs. 32, 36), measure from 25 to $40 \mu$ in diameter, and bear from 25 to 35 placoliths, while the daughter-cells are always spheroidal in shape, measure from ro to $22.5 \mu$ in diameter, and bear from 8 to 17 placoliths. Sometimes the two C. pelagicus cells, product of the first division of the mother-cell (Figs. 38, 39), separate before the second fission; their size is from 20 to $30 \mu$ and they bear from 16 to 28 placoliths. The placoliths on all stages are generally ovate in surface view (Fig. 33) with a central oval pore, usually subdivided by a bar into two equal parts (Fig. 6, Pl. I; Fig. 33, Pl. IV), but it is not uncommon for the dividing bar to be lacking; they measure usually from 8 to II $\mu$ in length but lengths of from 4.4 to $13 \mu$ have been recorded. Placoliths circular in surface view, with a single central round pore, have also been observed, usually on daughter-cells, and placoliths abnormal in shape are also occasionally produced (Fig. 37). Thus, from the measurements obtained from culture the 
range of size of $C$. pelagicus cells that might be found in the sea is from to to $40 \mu$ with the cells bearing from 8 to 35 placoliths, the placoliths themselves varying from 4.4 to $13 \mu$ in length.

Although the natural emergence of a Crystallolithus motile cell from a C. pelagicus daughter-cell has not been witnessed, it is possible to force out the Crystallolithus cell from its covering by exerting slight pressure on a daughter-cell ready to liberate its contents. The cell which emerges has two chromatophores and is similar in appearance to the Crystallolithus cell illustrated in Fig. 7, Pl. II, except that the flagella and haptonema are lacking. Cells released in this way have a diameter $3-5 \mu$ less than that of the placolith covering. Normal release is by a pore produced by the casting off of a single placolith (Fig. 4I, Pl. IV), which can be seen frequently still attached by one edge to the empty daughter-cell.

Cultures of this organism have been started each month throughout the year by inoculating with the motile phase. In the spring, the $C$. pelagicus phase can occasionally be found in cultures $5-7$ weeks old, but at other times of the year the cultures are more usually IO-I2 weeks old, sometimes older, before the $C$. pelagicus phase is produced. C. pelagicus can persist in unialgal culture in a healthy condition for at least 12 months (records for longer period not yet available) without being subcultured and without the addition of nutrients other than those in the medium (Erd-Schreiber) when the culture was started. Our records for the I2-month period, for a number of cultures, show that there is a regular alternation of the motile Crystallolithus and the non-motile $C$. pelagicus phase during the period. The persistence in unialgal culture of this species for such a long period in a healthy and vigorous state, without requiring additional nutrients (including iron) for rapid growth, suggests that the phagotrophy shown by the motile Crystallolithus phase may be in part responsible for this behaviour.

For the years 1921-22, Lebour (1923) records C. pelagicus (non-motile phase) as occurring at all depths from the surface to $100 \mathrm{~m}$ almost all the year round from the Plymouth region, the western part of the Channel and outwards towards the Irish Sea and the French coast. It was most frequent in March and October and less frequent from June to August than in the remaining months. Our records, for the nanoplankton occurring at Stations $E_{1}$ and $L_{2}$ to 6 for $1957-59$, show that this phase occurs now much less commonly in the waters off Plymouth than it did in 1921 and 1922. In the three years $1957-59$ its presence was recorded during three periods only, September 1957 to January 1958 (frequent, surface to $70 \mathrm{~m}$ ), February and March 1959 (rare, surface to $20 \mathrm{~m}$ ), and October to December 1959 (frequent, surface to $70 \mathrm{~m})$.

The Crystallolithus phase, however, was recorded five times during the same period from the following stations and depths: E I, I7. ix. 57, Io $\mathrm{m}$ with C. pelagicus phase; L6, 15. x. 57, surface, with C. pelagicus phase; $\mathrm{L}_{5}$, 
9. vii. 58 , surface; $\mathrm{L}_{4}, 9$. vii. 58 , surface; $\mathrm{E}_{\mathrm{I}}, 26$. viii. 58 , surface. It has also been recorded from the southern Celtic Sea and the north-eastern Bay of Biscay in slope and oceanic water during March and April 1958, at a depth of $10-20 \mathrm{~m}$ but at no other depth. In March, the $C$. pelagicus phase was also present at $20 \mathrm{~m}$ in the oceanic water.

Recent records for the occurrence and distribution of the Crystallolithus and C. pelagicus phases can be found in Braarud, Gaarder \& Grøntved (1953), Gaarder \& Markali (1956), Smayda (1958), and for the C. pelagicus phase only, in Bernard (1942), Lecal-Schlauder (195I), Halldal (1953), and Gaarder (1954). For the Norwegian Sea in May 1948, Braarud, Gaarder \& Grøntved (1953) record the Crystallolithus phase as reaching a maximum density of $\mathrm{I} 7,500$ cells $/ 1$. at the surface and the $C$. pelagicus phase as reaching a maximum density of 20,000 cells $/ 1$. at $50 \mathrm{~m}$.

\section{DISCUSSION}

We have called this organism by the name in current usage (Schiller, 1930; Lecal-Schlauder, I95I; Kamptner, I954), C. pelagicus (Wallich) Schiller, and Mrs Karen Ringdal Gaarder has confirmed (private communication) that this name is the legitimate name for this organism.

When Gaarder \& Markali (I956) described Crystallolithus hyalinus they suggested it might be identical with Pontosphaera borealis Ostenfeld (I910), described from arctic water of the East-Greenland Sea, but they were doubtful because coccoliths $3-4 \mu$ long were recorded for $P$. borealis, while their preserved material of Crystallolithus had coccoliths only $2 \mu$ long. We have shown earlier that the coccoliths on the Crystallolithus phase can be up to $3.3 \mu$ long, and, as further supporting evidence of the two motile forms being identical, Ostenfeld (1910) nearly always found the non-motile Coccolithus pelagicus phase of Crystallolithus associated with the Pontosphaera borealis. In fact Ostenfeld (I9I0) states he found both Coccolithus pelagicus and Pontosphaera borealis in the outer part of the pack ice and outside it, the Coccolithus pelagicus was dead (contents having been released-authors), but the Pontosphaera was most probably living when caught. Smayda (I958) supports this finding of the two phases occurring together by means of his records from around Jan Mayen Island where he reports the presence of Crystallolithus hyalinus and Coccolithus pelagicus 'at similar temperatures in the same habitat coupled with an identical habitus' to that in which Ostenfeld found the Pontosphaera borealis. It now appears certain that Crystallolithus hyalinus is synonymous with Pontosphaera borealis Ostenfeld.

The occurrence of a haptonema in a coccolithophorid was recorded by von Stosch (1955) for a form closely resembling, but not identical with, Hymenomonas carterae (Braarud \& Fagerl.) Braarud. We have at the present time in culture in the Plymouth Collection three coccolithophorids, in addition 
to the Coccolithus pelagicus, which possess haptonemata. Two we have not yet related to any described species and the third is Pleurochrysis scherffelii Pringsheim (1955). In P. scherffelii the short haptonema is visible on the motile phase for only a very short period after release from the non-motile phase, since the coccoliths, which are produced gradually on the body surface, eventually mask it from view. This may also be the case for many other coccolithophorids and therefore many described forms may possess haptonemata which have not so far been detected, or alternatively, they have have been seen but not recognized in preserved material. For example, Prof. Chadefaud brought to our notice a paper by Schlauder (1945) in which she records three flagella in Pontosphaera triangularis, saying that the third flagellum appeared to be more rigid; it may therefore be a haptonema.

The secretion of coccoliths inside the cells of coccolithophorids has been recorded by a number of workers (see also p. 267), but the process by which they are produced inside the cell is still unknown. Prof. Manton's findings (Manton \& Parke, 1960, p. 282 of this number) from the examination under the electron microscope of sections of a small green flagellate, which possesses surface body scales, may be the answer also to the internal production of coccoliths; she found inside the body of Micromonas squamata Manton \& Parke evidence of the production of complete scales within more or less deep-seated vesicles. The large vesicles which appeared inside the Coccolithus pelagicus mother-cells prior to placolith deposition on the body surface suggest that coccoliths may originate in vesicles in a manner similar to scales.

There is little detailed and precise information available in the literature on the stages in the life history of coccolithophorids with the exception of the studies by Bernard (1948, 1949) on the life history of C. fragilis Lohm. Spore formation has been reported for some species and spores, morphologically different and more simple than the parent cell, have been recorded by Bernard (1938) for Rhabdosphaera subopaca Bern. and Scyphosphaera elegans (Ost.) Defl., suggesting that these two species may have a type of life history similar to the one we have recorded for Coccolithus pelagicus.

The few studies already published on the life history of coccolithophorids in culture-Braarud \& Fagerland (1946), Pringsheim (1955), von Stosch (1955, 1958), and the present work-as well as our unpublished records from the ten species we have in culture, show undoubtedly that a great deal of valuable knowledge concerning the behaviour of these organisms (e.g. the demonstration of phagotrophy) and the stages in their life history can be obtained from the study of cultures.

Kamptner (1958), in his recent classification of the Coccolithineae, places the motile Crystallolithus phase of $C$. pelagicus in the tribe Syracosphaereae and the non-motile phase in the tribe Coccolitheae, both tribes being placed in the family Coccolithaceae. If this organism is classified on the micro-structure of its coccoliths, however, according to the units proposed 
tentatively by Braarud et al. (I955) and Halldal \& Markali (1955), the motile Crystallolithus phase would be placed in the section with holococcoliths and the non-motile phase in the section with heterococcoliths. It appears, therefore, that a coccolithophorid, which produces two morphological types of coccolith, cannot be placed satisfactorily in the present systems adopted for the classification of the Coccolithophoridae, and so these systems need revision.

\section{SUMMARY}

The study of Crystallolithus hyalinus Gaarder \& Markali in culture has shown it to be the motile phase in the life history of the non-motile Coccolithus pelagicus (Wallich) Schiller; two distinct morphological types of coccolith can therefore be produced by different phases of the one species.

Additional information from living material is given to supplement the original description of the Crystallolithus phase; sculptured scales are recorded under the crystalloliths in the hyaline outer layer of the body. This phase possesses a haptonema as well as two acronematic flagella; it exhibits phagotrophy and shows an unusual procedure for the discarding of waste material; its swimming and reproductive behaviour are recorded. The stages in the development of the Coccolithus pelagicus phase from the Crystallolithus phase are described. The occurrence of the two phases in the sea off Plymouth is recorded for the years $1957-59$.

\section{REFERENCES}

BERNARD, F., I938. Coccolithophoridés nouveaux ou peu connus observés à Monaco en 1938. Arch. Zool. exp. gén., T. 81, pp. 33-44.

— 1942. Essai sur les facteurs de répartition des Flagellés calcaires. Ann. Inst. océangr. Monaco, T. 21, pp. 29-II2.

— 1948. Recherches sur le cycle du Coccolithus fragilis Lohm., Flagellé dominant des mers chaudes. F. Cons. int. Explor. Mer, Vol. I5, pp. 177-88.

— 1949. Remarques sur la biologie du Coccolithus fragilis Lohm., Flagellé calcaire dominant du plancton méditerranéen. Mém. Soc. Hist. nat. Afr. N., T. 2, pp. $2 \mathrm{I}-8$.

Braarud, T., Deflandre, G., Halldal, P. \& Kamptner, E., 1955. Terminology, nomenclature and systematics of the Coccolithophoridae. Micropaleontologist, Vol. I, pp. 157-9.

BRAARUD, T. \& FAgERLAND, E., I946. A Coccolithophoride in laboratory culture. Syracosphaera carterae n.sp. Avh. norske VidenskAkad., No. 2, pp. I-IO.

BRAarud, T., GaARDER, K. R. \& GRøNTVED, J., 1953. The phytoplankton of the North Sea and adjacent waters in May 1948. Rapp. Cons. int. Explor. Mer, Vol. I33, pp. I-87.

GAARDER, K. R., I954. Coccolithineae, Silicoflagellatae, Pterospermataceae and other forms from the 'Michael Sars' North Atlantic Deep Sea Expedition I9I0. Rep. Sars N. Atl. Deep-Sea Exped., Vol. 2, No. 4, pp. I-2I.

GAARDER, K. R. \& MARKALL, J., I956. On the coccolithophorid Crystallolithus hyalinus n.gen., n.sp. Nytt Mag. Bot., Vol. 5, pp. I-5. 
Halldal, P., 1953. Phytoplankton investigations from Weather Ship $M$ in the Norwegian Sea 1948-49. Hvalråd. Skr., No. 38, pp. I-9I.

HALldAL, P. \& MARKali, J., I955. Electron microscope studies on coccolithophorids from the Norwegian Sea, the Gulf Stream and the Mediterranean. Avh. norske VidenskAkad., No. I, pp. I-28.

KAMPTNER, E., I954. Untersuchungen über den Feinbau der Coccolithen. Arch. Protistenk., Bd. Iоo, pp. I-9o.

— 1958. Betrachtungen zur Systematik der Kalkflagellaten, nebst Versuch einer neuen Gruppierung der Chrysomonadales. Arch. Protistenk., Bd. I03, pp. 54-I I6.

Lebour, M. V., 1923. Coccolithophora pelagica (Wallich) from the Channel. F. mar. biol. Ass. U.K., Vol. 13, pp. 271-5.

LECAL-SCHLAUDER, J., I95I. Recherches morphologiques et biologiques sur les Coccolithophorides Nord-Africains. Ann. Inst. océanogr. Monaco, T. 26, pp. 255362.

Ostenfeld, C. H., I9Io. Marine Plankton from the East-Greenland Sea. I. List of diatoms and flagellates. Medd. Gronland, Bd. 43, pp. 257-85.

Parke, M., Manton, I. \& Clarke, B., I955. Studies on marine flagellates. II. Three new species of Chrysochromulina. F. mar. biol. Ass. U.K., Vol. 34, pp. 579-609. 1956. III. Three further species of Chrysochromulina. Vol. 35, pp. 387-4I4. 1958. IV. Morphology and microanatomy of a new species of Chrysochromulina. Vol. 37, pp. 209-28. 1959. V. Morphology and microanatomy of Chrysochromulina strobilus sp.nov. Vol. 38, pp. I69-88.

Pringsheim, E. G., I955. Kleine Mitteilungen über Flagellaten und Algen. I. Algenartige Chrysophyceen in Reinkultur. Arch. Mikrobiol., Bd. 21, pp. 40I-IO.

SCHILlER, J., 1930. Coccolithineae. Kryptogamenflora, Bd. IO, H. 2, pp. 89-273.

SCHLAUder, J., I945. Recheres sur les Flagellés calcaires de la Baie d'Alger. $55 \mathrm{pp}$. [Diplôme d'études, Univ. d'Alger.]

SMAYDA, T. J., 1958. Phytoplankton studies around Jan Mayen Island, MarchApril 1955. Nytt Mag. Bot., Vol. 6, pp. 75-96.

SтоsсH, H. A. v., 1955. Ein morphologischer Phasenwechsel bei einer Coccolithophoride. Naturwissenschaften, Jg. 42, p. 423.

- 1958. Der Geißelapparat einer Coccolithophoride. Naturwissenschaften, Jg. 45, pp. I40-I.

WALLICH, G. C., I86r. Remarks on some novel phases of organic life, and on the boring powers of minute Annelids, at great depths in the sea. Ann. Mag. nat. Hist., Ser. 3, Vol. 8, pp. 52-58.

- 1877. Observations on the Coccosphere. Ann. Mag. nat. Hist., Ser. 4, Vol. I9, pp. $342-350$.

\section{EXPLANATION OF PLATES I-IV \\ Coccolithus pelagicus (Wallich) Schiller}

\section{I}

Electron micrographs of shadow-cast whole mounts taken with a Philips microscope carrying a $25 \mathrm{~A}$ pole-piece with astigmator, used at $60 \mathrm{kV}$.

Fig. I. Two Crystallolithus cells with bodies completely covered by crystalloliths. Exposure M 577.14, magnification $\times$ I400.

Fig. 2. Part of a Crystallolithus cell showing a coiled haptonema between the two flagella. Exposure M 577.17, magnification $\times c .8000$.

Fig. 3. Crystalloliths and translucent plate-scales from the motile Crystallolithus phase, direct print. Exposure $M$ 577.6, magnification $\times 23,000$. 

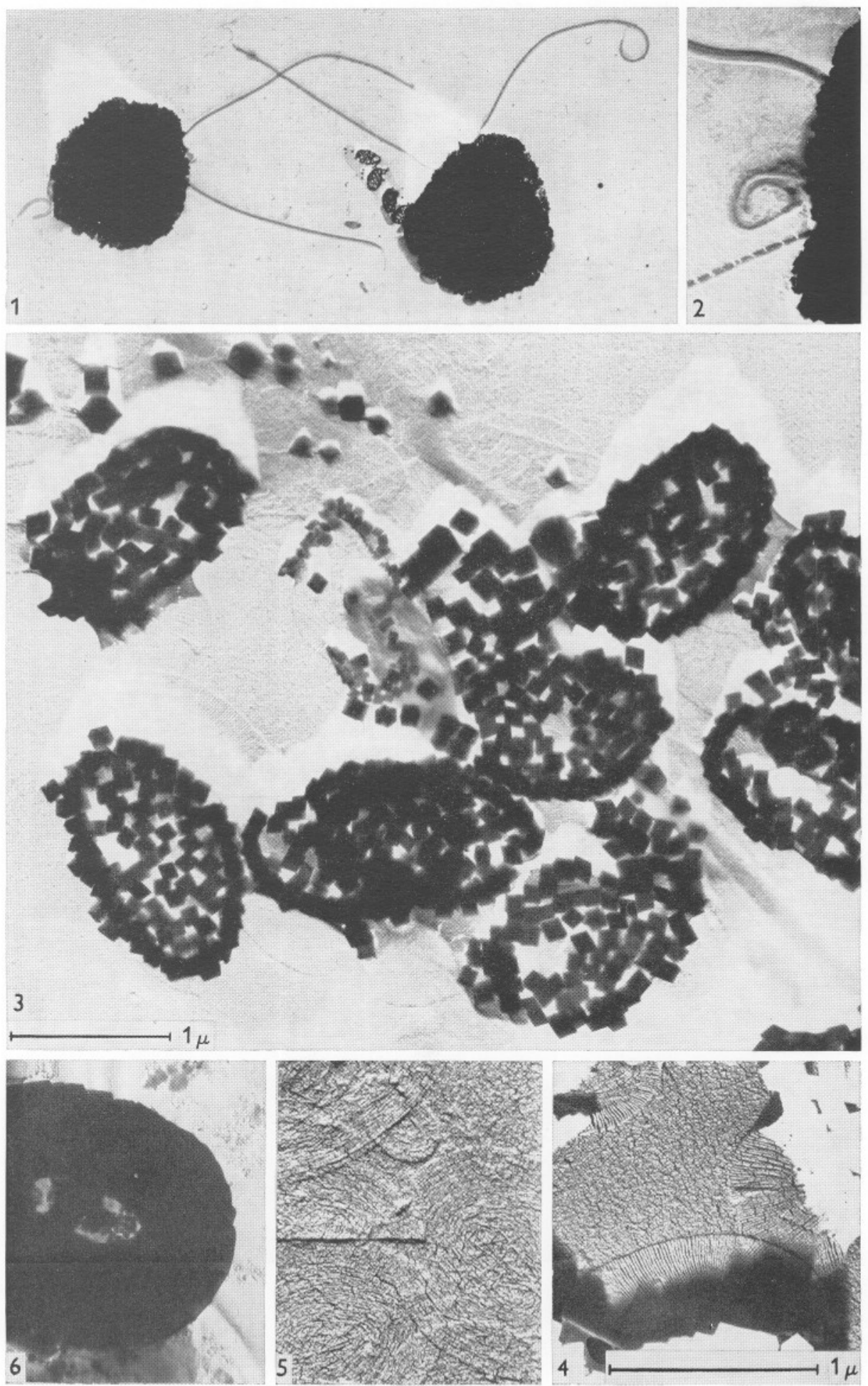

(Facing p. 272) 

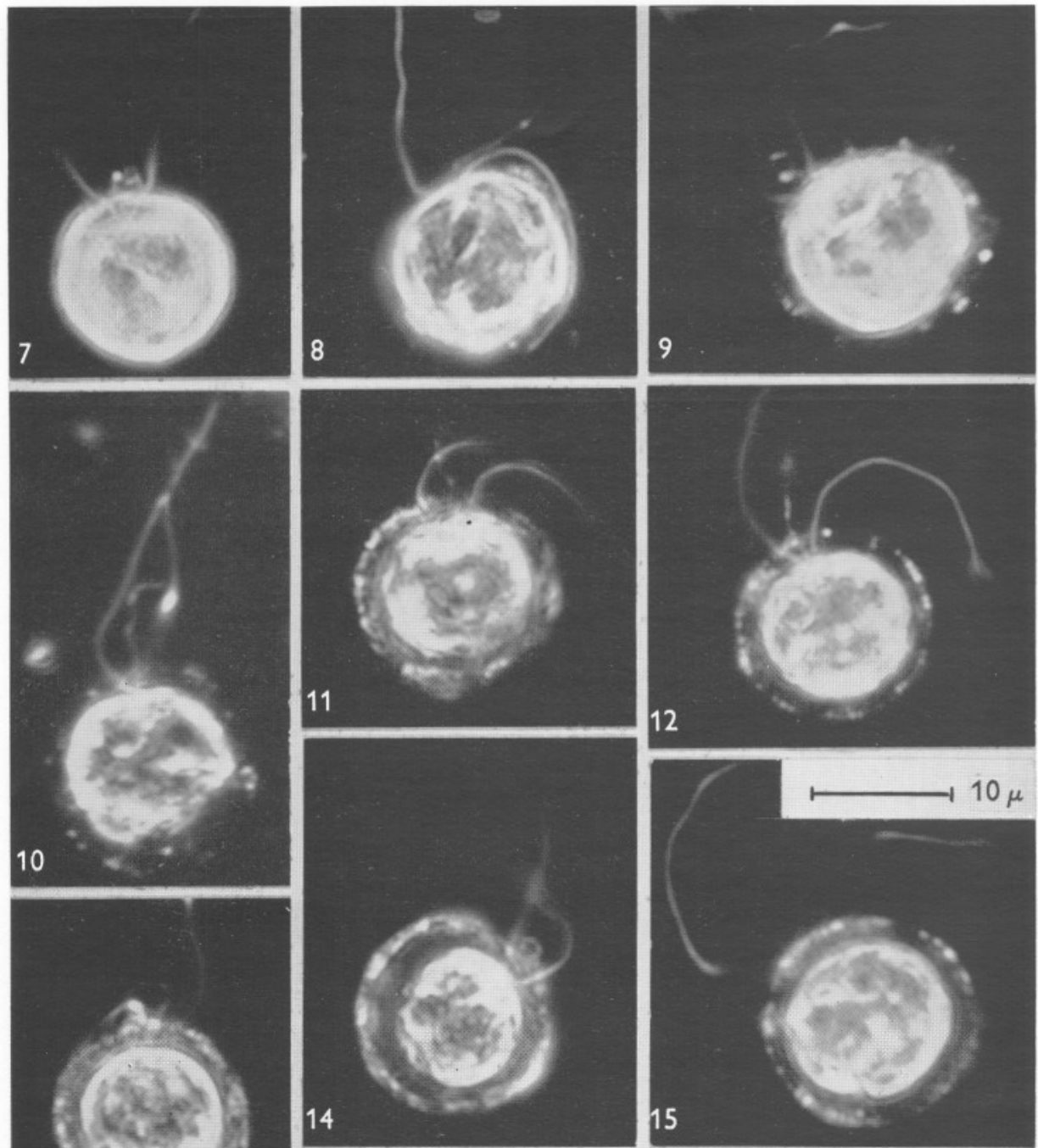

13
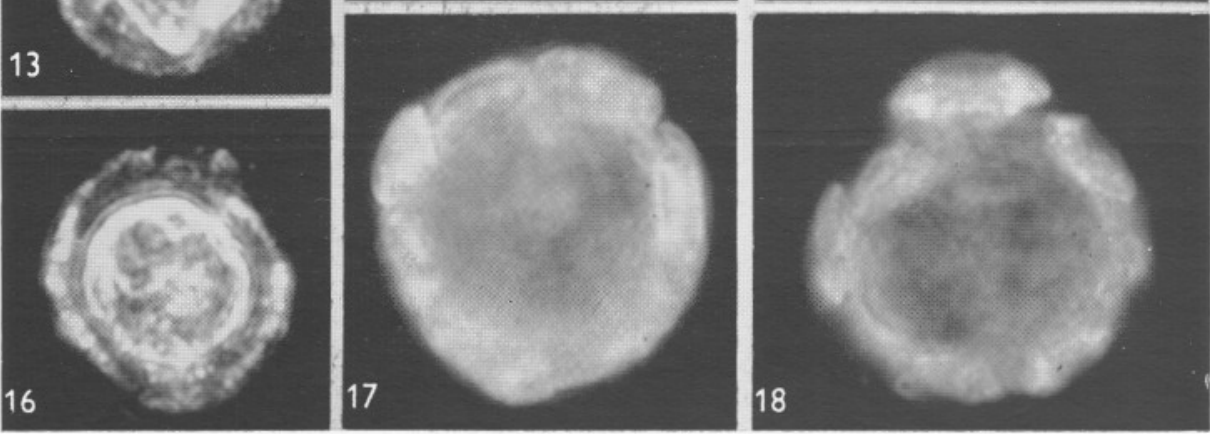


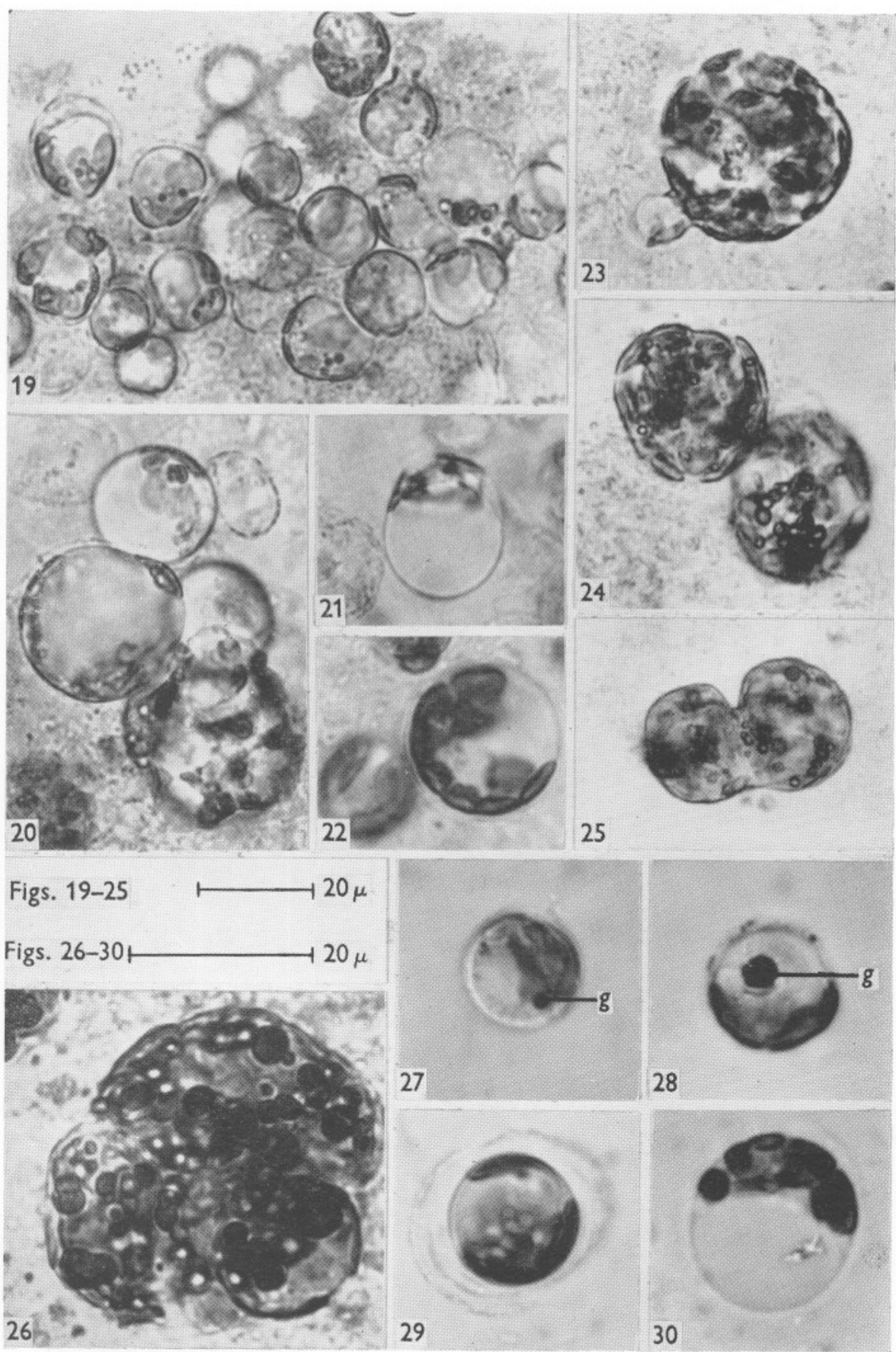



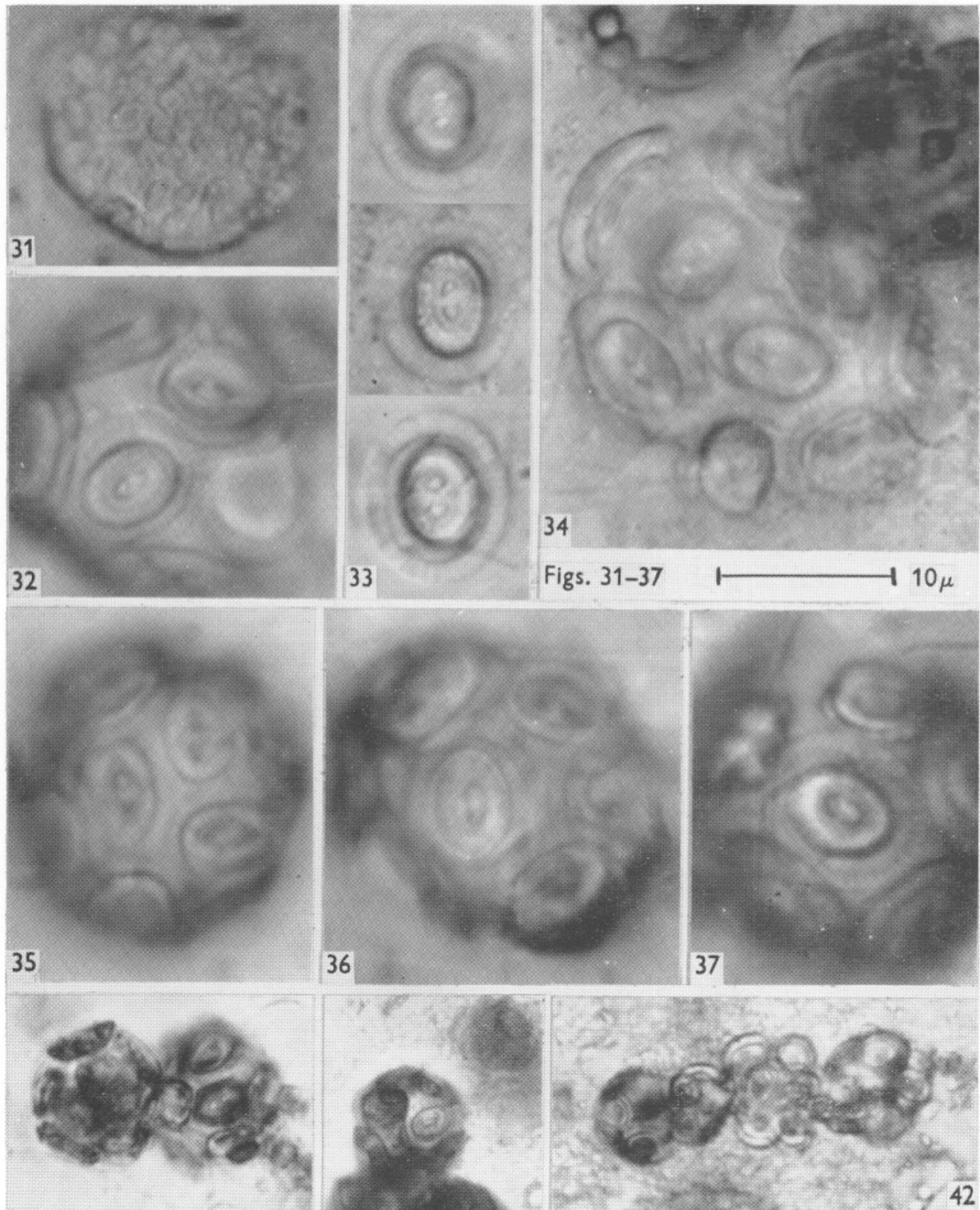

38

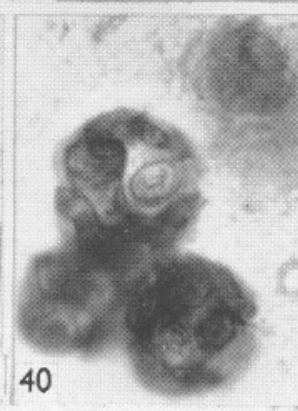

Figs. $38-42$

$20 \mu 40$
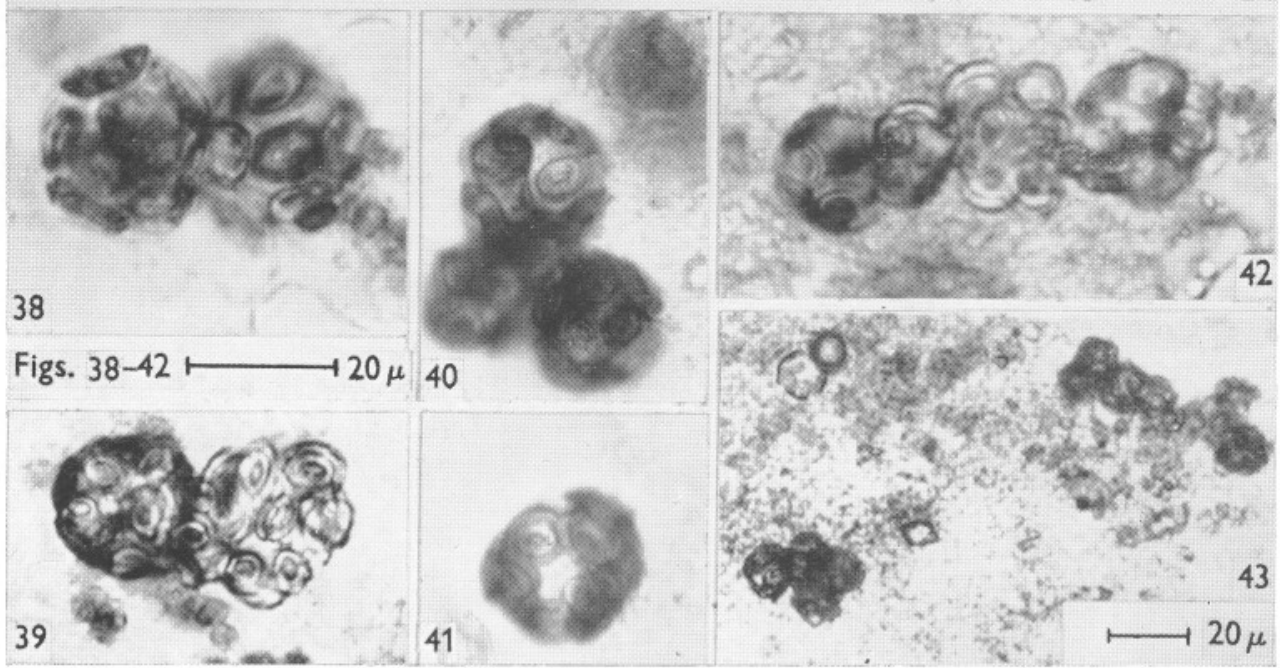
Fig. 4. Part of the field of fig. 3, reversed print, to show details of the markings on one side of the scales on which the crystalloliths are deposited. Exposure M 577.6, magnification $\times 30,000$.

Fig. 5. Another field as fig. 4 but showing the markings on the other side of the scales. Exposure M 577.8, magnification $\times 30,000$.

Fig. 6. Part of a placolith from the non-motile Coccolithus pelagicus phase. Exposure S. 686.7, magnification $\times c$. 6000 .

$$
\text { II }
$$

(Figs. 7-16, $\times$ 1650, Crystallolithus phase; Figs. 17, 18, $\times$ I650, Coccolithus pelagicus phase.)

Fig. 7. Cell lacking visible hyaline layer round body; no crystalloliths formed.

Fig. 8. Cell with fully extended haptonema visible between the two flagella; very few crystalloliths present in outer thin hyaline layer of body.

Fig. 9. Cell with haptonema coiled and thin hyaline layer, few crystalloliths.

Fig. 10. Cell with two flagella, unequal in length, and haptonema fully extended; hyaline layer round body thicker than in fig. 9 .

Figs. II-I4. Series of cells to show increase in thickness of hyaline layer round body and also the increase in the number of crystalloliths on the scales in this layer.

Fig. 15. Early fission stage.

Fig. 16. Non-motile Crystallolithus cell from bottom of a flask.

Fig. 17. Daughter-cell of Coccolithus pelagicus phase immediately after formation showing very thin hyaline layer covering the placoliths round the body.

Fig. 18. Same cell as fig. I7 after slight squashing to burst outer layer.

\section{III}

(Figs. 19-25, $\times 750$; figs. $26-30, \times 1250$. Figs. 19-26, 29-30: stages in the development of the non-motile Coccolithus pelagicus mother-cell.)

Fig. 19. A group of non-motile Crystallolithus cells from a sample of the skin taken from the bottom of a flask.

Fig. 20. Four cells at different stages in development.

Fig. 21. Early stage with two chromatophores and very large leucosin vesicle.

Fig. 22. Later stage than fig. 2 I with eight chromatophores and large leucosin vesicle.

Fig. 23. Mother-cell with lobed chromatophores at later stage than figs. 20-22, showing increase in size and disappearance of large leucosin vesicle.

Fig. 24. Two mother-cells with numerous small vesicles inside; cells fixed with osmium tetroxide.

Fig. 25. A mother-cell starting to divide before the placoliths are deposited on the body surface.

Fig. 26. A mother-cell dividing to produce four daughter-cells before the placoliths are deposited on the outside; many vesicles, darkened by osmium tetroxide, clearly visible inside the body; thin hyaline outer layer showing round part of the cell.

Fig. 27. A Crystallolithus cell showing a small pellet of ingested graphite ( $g$ ).

Fig. 28. Another Crystallolithus cell showing a larger pellet of ingested graphite $(g)$.

Fig. 29. A non-motile Crystallolithus cell showing a thick striated hyaline layer round the body.

Fig. 30. Slightly later stage (at higher magnification) than Fig. 2 I with four dividing chromatophores and a large leucosin vesicle.

\section{IV}

(Figs. 31-37, $\times 2335$; figs. $38-42, \times 750$; fig. $43, \times 375$.)

Fig. 3I. Crystallolithus phase-empty hyaline casing containing the crystalloliths from which the daughter-cells emerged after fission of the parent-cell.

Fig. 32. Part of a C. pelagicus mother-cell, ovoid in shape, showing the overlapping of the placoliths on the body surface.

Fig. 33. Three placoliths from the C. pelagicus stage in surface view. 
Fig. 34. A C. pelagicus daughter-cell squashed to liberate the cell inside the placoliths; liberated cell lying beside placoliths.

Fig. 35. A C. pelagicus daughter-cell, spheroidal in shape.

Fig. 36. A small C. pelagicus mother-cell, ovoid in shape.

Fig. 37. A C. pelagicus daughter-cell showing placoliths of normal and abnormal shape.

Figs. 38-39. First fission of $C$. pelagicus mother-cell.

Fig. 40. Second fission of mother-cell to produce four C. pelagicus daughter-cells.

Fig. 4I. C. pelagicus daughter-cell from which contents have been liberated.

Fig. 42. Four C. pelagicus daughter-cells united together in a linear series, as described for a coccolithophorid by Wallich (1861, I877).

Fig. 43. Low power photograph of groups of four $C$. pelagicus daughter-cells from sample of the skin taken from the bottom of a flask. 